\title{
AVALIAÇÃO GEOAMBIENTAL DA ZONA COSTEIRA DO BAIRRO DE CANDEIAS, PERNAMBUCO
}

\author{
Msc. Maria Tereza Souza Pereira da Costa \\ Mestrado em Tecnologia Ambiental - ITEP \\ Rua Dom João Moura, 240, Engenho do Meio, CEP 50.730-030, Recife, PE, Brasil \\ Tel.: (55 81)3478.1025 - mestrado@itep.br \\ Prof $^{a}$. Dr ${ }^{\mathrm{a}}$. Niédja Maria Galvão Araújo e Oliveira \\ noliveir@oi.com.br
}

\begin{abstract}
RESUMO
A proteção e recuperação de praias constituem hoje uma preocupação em escala planetária. Na costa do Brasil, mais especificamente no município de Jaboatão dos Guararapes, bairro de Candeias - PE, a situação não difere do contexto. Uma série de intervenções antrópicas acompanhadas de um processo de ocupação/urbanização desordenado, não respeitando os limites naturais da costa, desencadearam uma situação preocupante. O presente trabalho teve por objetivo analisar a geomorfologia costeira, determinar a morfodinâmica praial e identificar os processos costeiros atuantes, onde se caracterizam os diferentes níveis de degradação ambiental.
\end{abstract}

Palavras-Chave: Erosão costeira, morfodinâmica praial, degradação ambiental, ocupação urbana.

\begin{abstract}
The protection and recuperation of beaches is today a concern around the world. In the coast of Brazil, specifically in Jaboatão dos Guararapes, in Candeias, the situation is no different from any other. Many human interventions follow a disorganized process of occupation and urbanization which does not respect the limits of the natural coast making an alarming situation. This work have the objective to analyse the geomorphology of the coast to determine a morph- dynamic model of the beach and identify the important beach processes to characterize different levels of environmental degradation.
\end{abstract}

Key word: Coastal erosion, beach morph-dynamics, environmental degradation, urban occupation

\section{RESUMEN}

La protección y la recuperación de las playas es actualmente una preocupación mundial. En la costa de Brasil, específicamente en el municipio de Jaboatão dos Guararapes, en el barrio de Candeias - PE, la situación no es diferente. Una serie de intervenciones humanas y un proceso de ocupación/urbana desordenado, que no respectó los límites naturales de la costa, provocó una situación preocupante. Este estudio tuvo como objetivo examinar la geomorfología costera, la morfodinámica de las playas, determinar y identificar los procesos costeros activos, que caracterizan los diferentes niveles de degradación del medio ambiente.

Palabras-clave: Erosión costera, morfodinámica de las playas, degradación del medio ambiente, ocupación urbana.

\section{INTRODUÇÃO}

A zona costeira de Pernambuco tem suportado um grande crescimento, sendo área que apresenta maior densidade demográfica do Estado. É também nessa área que se verifica a concentração de atividades econômicas, industriais, de recreação e turismo, e, conseqüentemente, dos problemas ambientais delas decorrentes, dentre os quais a erosão marinha. Ao longo da costa pernambucana observam-se em alguns locais desequilíbrios em relação ao balanço sedimentar, que é evidenciado pela erosão marinha progressiva que varia de moderada a severa.

Nos últimos anos a intensificação do uso da área costeira de Candeias, aliada a sua extrema fragilidade, tem-se constituído numa preocupação crescente quanto ao futuro desta zona. A erosão marinha representa um grave problema que afeta quase toda costa do município de Jaboatão dos Guararapes, o que torna complexo prever uma proteção para toda extensão da costa. Diante da elevação do nível relativo do mar, da crescente pressão do desenvolvimento costeiro, do aumento da demanda do turismo e da preocupação, a longo termo, com o declínio da qualidade natural do 
ambiente, o gerenciamento da zona costeira de Pernambuco tornou-se assunto a ser materializado em uma máxima brevidade. Nesse sentido, torna-se claro a necessidade de ampliar e melhorar a superfície disponível da praia existente, sugerindo implementações adequadas, preferencialmente mediante soluções, com emprego de tecnologia pouco agressiva e de baixo impacto.

O conjunto de ações propostas, se implementado, pretende que o litoral do município de Jaboatão dos Guararapes possa recuperar parte de sua primitiva natureza, melhorando suas condições, para ser desfrutado por todos. A principal vantagem da regeneração da praia, além daquela de natureza econômica e funcional, como sistema de defesa eficiente contra a ação humana e do mar, é a de recuperar um espaço de grande valor ambiental e sócio-econômico (COUTINHO, 1997).

Aárea objeto de pesquisa compreende um trecho da zona costeira do município de Jaboatão dos Guararapes, Estado de Pernambuco, Nordeste do Brasil, que se estende desde as proximidades da curva do SESC, início da praia de Candeias, até a entrada do estuário de Barra de Jangada, situado na posição geográfica entre a latitude $8^{\circ} 11^{\prime} 59^{\prime \prime} / 8^{\circ} 13^{\prime} 14^{\prime \prime}$, e longitude $34^{\circ} 54^{\prime} 86^{\prime \prime} / 34^{\circ} 55^{\prime} 29^{\prime \prime} \mathrm{W}$ ( Figura 01).

O espaço em foco é caracterizado pela presença de planície de restinga, formada durante o Quaternário, mais especificamente no Holoceno, apresentando atualmente extensa praia retilínea, resultado de sua forma acumulativa, enseadas, e um importante pontal arenoso denominado restinga de Candeias, nas proximidades do estuário de Barra de Jangada, do tipo dominado por marés, apresentando uma dinâmica muito intensa.

Este trecho de costa apresenta-se como uma área dinâmica em contínua evolução, que prograda de sul para norte, de acordo com o sentido preferencial das correntes litorâneas. As últimas seis décadas mostram a evolução das linhas de costa, que traduzem o olhar do objetivo central do presente trabalho em realizar estudos sobre as condições morfodinâmicas e sedimentológicas e os processos atuantes que contribuíram para a descaracterização paisagística do Bairro de Candeias/PE.

Atualmente os pesquisadores e especialistas em planejamento e gestão, enfrentam problemas complexos com respeito ao uso e administração dos recursos contidos no espaço costeiro, pois os processos naturais, sociais e políticos implicados são diversos.

Quando se trata de propostas conceituais sobre o sistema costeiro, os pesquisadores ditam normas interativas sem considerar que este sistema é unitário, composto por um conjunto de interrelações entre a água do mar, a terra firme e, em ocasiões, os fluviais. (OLIVEIRA, 1998).

Os aspectos físicos (unidades geomórficas, climáticas e ecológicas resultantes) complementam os de natureza humana (demográficas, econômicas, etc). Ambos estão relacionados com os aspectos sociais, históricos, políticos, de equipamentos e serviços. As funções destes fatores geram respostas diferenciadas na distribuição territorial. Posteriormente, o espaço comum da interação entre cada unidade considerada, proporciona uma aproximação dos limites requeridos. A ponderação de cada fator dependerá do objetivo incluído previamente.

Indiscutivelmente se constata como fator comum conceitual, a existência de uma zona variável em concordância da diversidade e o dinamismo, que aparece como resultado do processo de contato dinâmico entre a hidrosfera (output) e a litosfera (input). Estes meios estão integrados à atmosfera, tendo um caráter mais de integração do que de definição.

Segundo Oliveira (1998), os fatores conceituais de litoral podem ser definidos como: zona submarinha, zona de ação por hidrodinâmica marinha e zona limitada pela linha de costa até onde a profundidade aumente bruscamente. A definição do litoral representa um problema científico à definição de limites precisos que são válidos, constitui uma dificuldade derivada da própria essência do tipo de fenômeno analisado.

Tem-se uma atenção especial para o estudo das restingas como forma acumulativa, frágil por sua natureza e forma de ocupação. .As restingas e mangues, situados na costa e no litoral de Jaboatão, pertencem ao mundo de clima tropical, com o sistema climático bem definido (estações secas e chuvosas) de totais pluviométricos bem distribuídos, colonizados por vegetação herbácea, arbustiva e arbórea. 


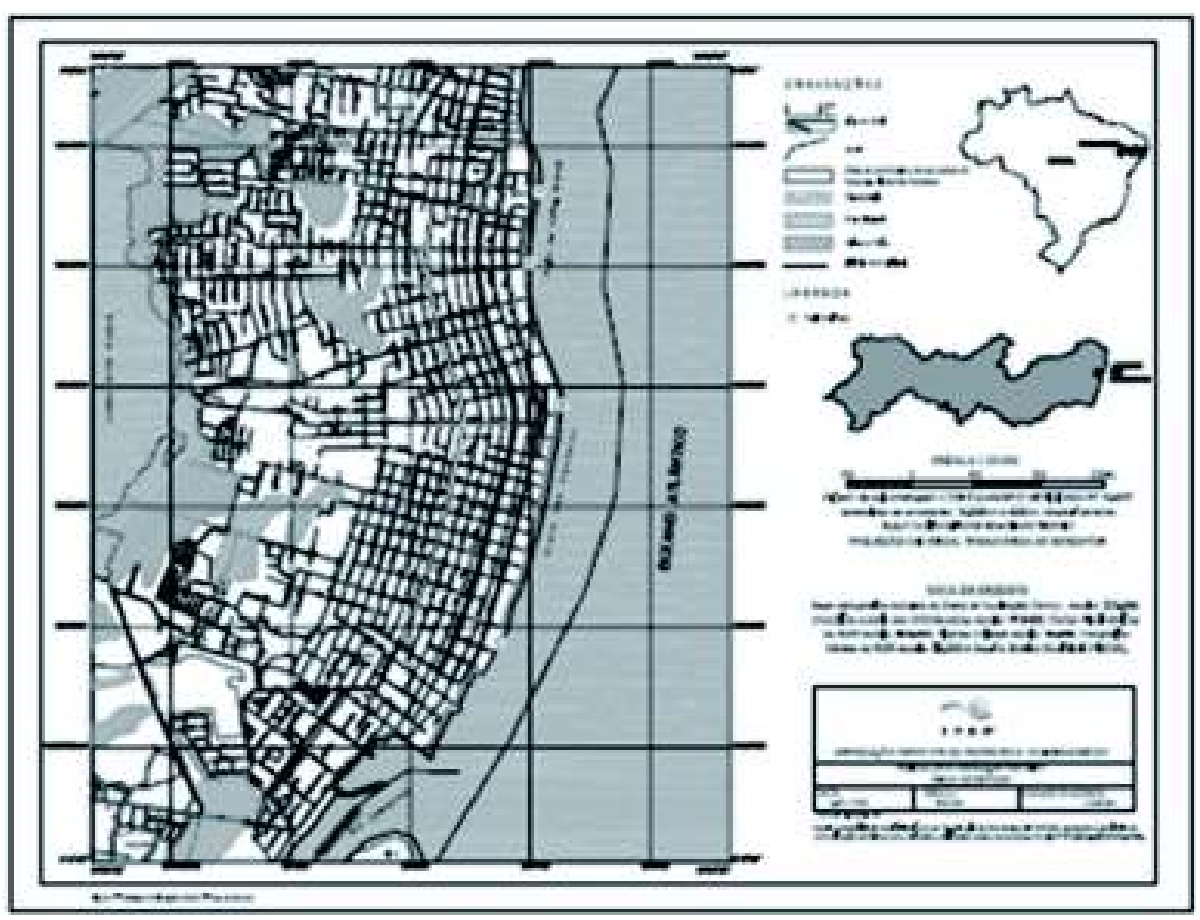

Figura 1 - Localização Geográfica

A morfodinâmica das restingas implica uma variedade de forma que nem sempre são entendidas como tal. Entre elas, se encontram esporões, tômbolos, calda de cometa e flechas.

No que se refere aos mangues, a literatura especializada faz alusão aos aspectos fito e zoogeográfico, como se a distribuição dos seres vivos não estivesse ligada a outros elementos geográficos. Estes fatores formam parte dos processos de estímulo-resposta ao meio, onde a colmatação de sedimentos é um dos elementos condicionantes. Mangue é uma forma do relevo plano, levemente inclinado, fluido, depositado nas depressões de contato fluviomarinho em um ambiente caracterizado por uma rede de drenagem dendrítica pinada ou dendrítica anastomosada; e constituída geralmente por argila, matéria orgânica e areia, formando parte do sistema costeiro.

Ao longo do litoral do nordeste brasileiro, a faixa sedimentar costeira que constitui geralmente um relevo de tabuleiros e colinas, é, às vezes, interrompida por pequenas planícies que penetram até $15 \mathrm{~km}$ continente adentro, semelhante aquela na qual foi erguida parte da Região Metropolitana do Recife (FILHO et al. 1991).

Tendo a planície de Jaboatão dos Guararapes uma origem indubitavelmente tectônica, seu início deve ter estreitas relações com o Lineamento Pernambuco e a abertura do Oceano Atlântico. Segundo DUARTE, (2002)), são passíveis de identificação três direções principais de falhamentos: o Lineamento Pernambuco de direção E-W, falhas normais de direção NE-SW associadas à abertura do Oceano Atlântico e falhas na direção NW-SE, responsáveis pela implantação de um rifte ao sul do Lineamento Pernambuco.

Sabe-se, também, que os estilos tectônicos ao norte e ao sul deste lineamento apresentam características bem distintas quando comparados, o que confere a referida planície uma formação complexa, de difícil reconstituição para períodos pré-Quaternário. Sendo assim, a partir da deposição do Grupo Barreiras (Plioceno-Pleistoceno), forma-se um cenário no qual posteriores eventos geológi$\cos$ irão desenvolver um papel fundamental na formação da planície de Jaboatão dos Guararapes.

O fato é que a evolução da atual planície está diretamente relacionada às variações do nível do mar, que ocorrem durante todo o Quaternário, em decorrência de mudanças climáticas globais. $\mathrm{O}$ registro dessas oscilações é reconhecido em grande parte do litoral brasileiro e está relacionado a dois grandes episódios transgressivos denominados por Bittencourt et al. (1979 citado por DUARTE, 2002), de Penúltima Transgressão (120.000 anos A.P.) e Última Transgressão (5.100 anos A.P.).

Mercator - volume 8, número 17, 2009: set./dez. 
Conhece-se, ainda, um nível marinho alto, mais antigo que 120.000 anos A.P. Trata-se, segundo Suguio et al. (1985), de um evento mal definido devido a incertezas na identificação de seus afloramentos.

A área estudada pertence à faixa costeira sul de Pernambuco, está limitada a norte pelos rios que deságuam na Bacia do Pina; ao sul pelos terraços marinhos do município de Jaboatão dos Guararapes; a oeste encontramos as primeiras exposições das colinas do Grupo Barreiras e dos terraços pleistocênicos contíguos; e a leste, limita-se com o oceano Atlântico, através de uma faixa de praia contínua com direção geral NNE-SSW (DUARTE, 2002).

Face as discussões travadas entre os científicos da área, existe uma dicotomia de idéias entre o Grupo Barreiras e Formação Barreiras. Estes termos tem sido motivo de discussões acadêmicas ao longo da história. As autoras optaram na utilização da terminologia Grupo Barreiras.

O grupo Barreiras é representado por sedimentos areno-argilosos do Plioceno-Pleistoceno (com idade em torno dos 2 milhões de anos), que recobrem indistintamente o embasamento cristalino e a maior parte dos sedimentos cretáceos da faixa litorânea de Pernambuco citado por (DUARTE, 2002). Uma linha de falésias fósseis marca o limite destes depósitos com a planície costeira quaternária cuja existência depende do maior ou menor recuo dessas falésias (CHAVES, 1996). A deposição desta formação se deu, sob a forma de leques aluviais e de depósitos fluviais de canais entrelaçados, encontrando-se, ainda, em algumas porções, fácies flúvio-lagunares e de planícies aluviais. As fácies fluviais é dominante no Grupo Barreiras, representando aproximadamente 70\% de sua área ao longo de toda faixa sedimentar costeira, em cotas que variam de 40 a 80 metros (DUARTE, 2002).

Os Terraços Marinhos Pleistocênicos e Holocênicos são os registros sedimentares de dois períodos regressivos que marcaram profundamente a evolução da planície de Jaboatão dos Guararapes. O primeiro deles no Pleistoceno (após máximo transgressivo de 120.000 anos A.P.), e o segundo no Holoceno (após o máximo transgressivo de 5.100 anos A.P.).

Foram originalmente descritos por Carvalho \& Coutinho (1979) na região em torno da Lagoa Olho d'Água (sul da área estudada), que, entretanto, atribuiram-lhe uma idade Holocênica. Os terraços marinhos Pleistocênicos representam uma unidade morfológica aplainada que ocorre na porção mais interna da planície, ora ao sopé das formações mais antigas (principalmente o Grupo Barreiras), tal como visto nas proximidades do Aeroporto dos Guararapes, ora como corpos isolados com formas das mais variadas. Quando alongadas, tendem a ser paralelos à atual linha de costa. Possuem cotas variando entre 6 e $10 \mathrm{~m}$ e larguras entre 0,5 e $1,5 \mathrm{~km}$.

São constituídos por areias quartzosas inconsolidadas (em superfície), de granulometria média/ grossa, com coloração branca ou acinzentada, marcadas pela ausência de conchas de moluscos, dissolvidas pela ação de ácidos húmicos, que por sua vez, em combinação com o óxido de ferro, geram em profundidade areias mais compactas e escuras, resultado de processos pedogenéticos (formação podzol).

DUARTE (2002), descreve, o que chamou de Terraços Marinhos Pleistocênicos Modificados, que correspondem a uma parte dos terraços acima descritos e que foram profundamente alterados pela ação dos rios. Assim, seu comportamento em subsuperfície é bastante irregular, ora dominando areias retrabalhadas, ora depósitos de argilas orgânicas.Os Terraços Marinhos Holocênicos ocorrem na porção externa da planície como uma unidade bem individualizada, com forma alongada, essencialmente contínua e paralela à atual linha de costa. São constituídos por areias quartzosas inconsolidadas, de granulometria média/grossa, de coloração branca ou acinzentada, normalmente rica em conchas de moluscos e restos vegetais, e que são considerados elementos de diferenciação entre estes terraços e os de idade pleistocênica. Soma-se a isso, a ausência da cimentação basal escura, típica dos Terraços Pleistocênicos.

Outra característica marcante dos Terraços Holocênicos é a existência de antigas e estreitas linhas de cordões litorâneos, que marcam pretéritas posições da linha de costa. Hoje, devido à intensa ocupação urbana que se verifica nestas áreas, estes cordões não mais são observados, exceção para pequenas ocorrências presentes nas porções frontais na Lagoa Olho d'Água. 
Nos arredores de Jaboatão dos Guararapes, esta fácies é representada por areias feldspáticas, com um colorido forte e diversificado, os sedimentos têm boa seleção e baixo grau de arredondamento. São comuns os pavimentos de seixos de quartzo subarredondados a subangulosos.

Estes depósitos são geralmente recobertos pelos depósitos de leques aluviais distais, constituídos por areias grossas a conglomeráticas recobertas por pelitos com repetição vertical desse padrão, denunciando, assim, o caráter cíclico da deposição (ALHEIROS \& FILHO, 1991 citado por DUARTE, 2002).

Adotam-se os termos depósitos fluviais e flúvio-lagunares, para caracterizar os sedimentos formados devido ao afogamento da região durante a Última Transgressão, e que na regressão subseqüente foram depositados em antigas depressões. Posteriormente, devido ao aumento do gradiente continental, sofreram os efeitos da ação fluvial, marcada pela deposição de sedimentos arenosos. São encontrados na porção interna da planície, em zonas baixas que separam os terraços Pleistocênicos dos Holocênicos, e estes dos sedimentos do Grupo Barreiras. Os sedimentos formados pela influência lagunar são geralmente lamosos, ocorrendo em regiões com intensa atividade biológica. Já os depósitos fluviais ocupam, principalmente, os vales cujas cotas raramente ultrapassam os 10 m (BORBA, 1999).

Depósitos de Mangue são encontrados normalmente na zona da Planície costeira protegida da ação das ondas, nas margens de canais de maré e nas porções distais de vales de rios e riachos, porém, sofrem freqüentemente a influência das marés, fato que geralmente se verifica na área encaixada entre os terraços marinhos da planície de Jaboatão dos Guararapes.

Essa área possui características geológicas e biológicas específicas, destacadas dos demais depósitos lagunares pela sua importância ambiental e por constituírem ecossistemas frágeis. São bem marcadas por exibirem uma vegetação típica, a vegetação de mangue, na qual parece haver ao longo de toda a costa pernambucana, um predomínio de três espécies: Rhizophora mangle, Avicennia schaueriana e Laguncularia racemosa, materializando a área em estudo. São constituídos por sedimentos argilo-sílticos, de cores escuras, ricos em matéria orgânica, restos de madeira e conchas. Apresentam normalmente um gradiente granulométrico, onde as partículas mais grosseiras estão no fundo dos canais, enquanto que as mais finas encontram-se nas margens.

Os Recifes de Arenito e de Algas Coralíneas mostram um dos traços morfológicos mais característicos do litoral de Jaboatão dos Guararapes, bem como de todo o restante do litoral nordestino. Ocorrem como corpos lineares, nem sempre contínuos, dispostos paralelamente à costa. Desempenham uma importante função no delineamento da recente zona costeira, pois se comportam como uma proteção natural diante da ação das ondas e marés, o que, na prática, controla parcialmente a distribuição dos sedimentos transportados pelas correntes litorâneas.

Os Sedimentos de Praia formam a estreita faixa da atual zona de praia, cuja largura não costuma exceder a algumas dezenas de metros, que naturalmente delimita a porção mais externa da planície costeira. Estes sedimentos encontram-se depositados entre a linha de baixa-mar e os terraços Holocênicos, tendo, geralmente, uma pequena inclinação no sentido do mar, cuja principal característica é estar permanentemente submetida à ação combinada das ondas, corrente de deriva litorânea e das marés. Sua composição é predominantemente representada por areias quartzosas (de variada granulometria), e por proporções subordinadas de fragmentos bióticos e minerais pesados.

\section{ENFOQUE METODOLÓGICO E ABORDAGEM DE PROCEDIMENTOS}

A visão holística do espaço e da necessidade de compreensão das relações entre os homens e a natureza cria novos enfoques e visões nas pesquisas ambientais. Para atender os objetivos desta pesquisa, o enfoque tem como unidade básica à análise sistêmica e integral, as influências, os determinantes, as trocas e processos de diferentes níveis, de modo que permitam estudar o conjunto de relações entre eles, visto pela ótica de um diagnóstico geoambiental. 
A pesquisa define o conhecimento dinâmico, com ambientes acumulativos, porquanto se identificam as relações dos processos, como agentes formadores em diferentes escalas.

Os métodos e procedimentos estão em concordância com a natureza geográfica da investigação, o enfoque geoambiental, o universo constituído por uma zona de interação terra-mar, que compreende áreas acumulativas particulares; com o conjunto das influências diretas e indiretas, que se produzem sobre os elementos constituintes deste sistema, e as transformações que eles refletem. A partir daí, se utilizou um método para atender às múltiplas necessidades de uma compreensão mais concreta do problema.

Os procedimentos efetuados consistiram, inicialmente em pesquisa bibliográfica do tipo temática, acerca dos principais fatores naturais e socioeconômicos, de materiais históricos relativos a descrição do processo de assimilação e do levantamento geomorfológico utilizando fotos áreas, ortofotocartas e imagens de satélite. Juntos, tais procedimentos possibilitaram um conhecimento prévio coerente em relação à morfologia, dinâmica, estado atual e outros elementos. Depois desta fase, foram realizadas várias campanhas de trabalho de campo com observações morfodinâmicas. Finalmente, se identificaram as ações, fatores e elementos e impactos.

A metodologia utilizada nesta pesquisa foi descrita no método de identificação e avaliação de impactos, se espelhou na avaliação de multicritérios adaptada por Oliveira (1998), nos modelos matriciais de Leopold \& Gómez (1994), para identificar e avaliar as transformações ocorridas a partir de um conjunto de ações humanas, dos fatores e elementos naturais (físicos, bióticos, perceptuais e socioeconômicos) alterados pela ação antrópica, e dos impactos produzidos, obtendo-se uma quantidade global e ponderada dos impactos positivos e negativos. Os critérios qualitativos e quantitativos utilizados foram: caráter do impacto, certeza, tipo, tempo em aparecer e magnitude, importância, duração e reversibilidade. Critérios para a valorização dos impactos adaptado por Oliveira (1998)

\section{RESULTADOS E DISCUSSÕES}

Através da análise da linha de costa, com imagens de ortofotocartas dos anos de 1974 e 1986 (Figuras 02 e 03, respectivamente), pode-se identificar uma regressão da mesma quando se visualiza uma perda substancial de areia nas praias.

A comparação das ortofotocartas permitiu calcular a evolução da linha de costa nesse intervalo de tempo, definir taxas de erosão/sedimentação e o grau de vulnerabilidade da costa. No presente estudo, o grau de vulnerabilidade foi determinado em função da tendência e recuo ou progradação da linha de praia. Associando esta vulnerabilidade com o grau de urbanização e de intervenções na faixa costeira, é possível fazer uma avaliação dos riscos que apresenta cada setor da praia. Analisando as imagens dos anos de 1974 e 1986, se vislumbrou uma agradação no setor da área de estudo, (Figuras 02 e 03).

Outro fator que deve ser chamado atenção é a construção do dique, concluída em 1988, que provocou várias modificações, entre elas o recuo da linha de praia, da flecha arenosa de cerca de 200m em relação à linha de 1983. Na margem esquerda do estuário, a erosão foi acelerada, provocando uma grande curvatura na linha de costa. A conclusão desse dique bem como a construção de um restaurante próximo à margem esquerda do estuário, provocou alterações nefastas à morfologia desse setor, fator preponderante para a escolha do local como sendo o primeiro perfil praial.

Dependendo do ângulo de incidência das ondas com a linha de praia, formam-se as correntes longitudinais e as correntes de retorno. Arrebentam-se paralela à linha de costa, desenvolve-se um padrão de circulação celular através de correntes de retorno que correm da praia para o mar e se dissipam rapidamente depois da linha de quebra das ondas. As correntes de retorno acabam por modificar a altura das ondas na zona de arrebentação, e depois de um determinado tempo, rearranjam os sedimentos do fundo, produzindo uma série de reentrâncias na linha de praia separadas pelos cúspides praiais, produzindo erosão). As ondas que quebram obliquamente sobre a praia 
desenvolvem as correntes litorâneas, através das quais as massas d'água deslocam-se paralelamente à linha de praia. $\mathrm{O}$ mesmo autor afirma que as correntes litorâneas são os principais agentes no transporte de sedimentos postos em movimento pela ação das ondas, ao longo de amplos trechos de costas arenosas. Entretanto nas proximidades do litoral a influência de outros fatores, tais como, a ação dos ventos, das marés, das descargas fluviais; a interação entre estes fatores e a morfologia do ambiente, torna os fluxos das correntes litorâneas bastante complexos. A costa de Pernambuco apresenta uma direção geral NE-SW, sofrendo uma inflexão, para Norte/Sul, de Olinda para o Norte até o limite com o estado da Paraíba, alterando a forma do trem de ondas que incide nas praias.

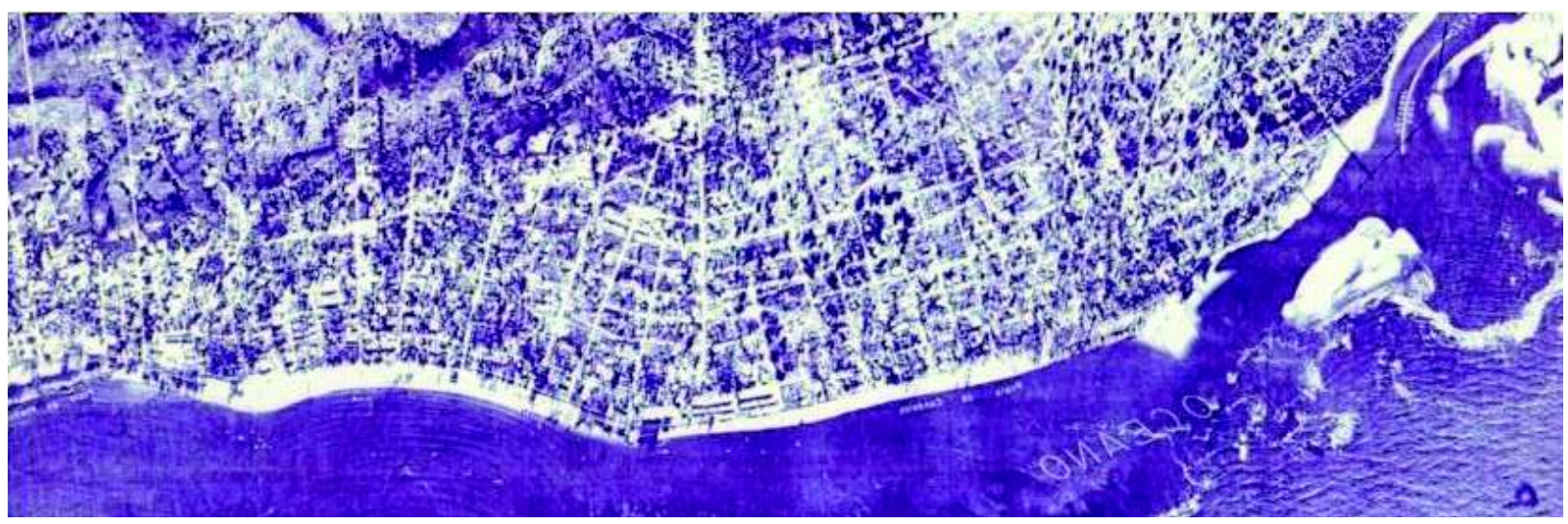

Figura 2 - Ortofotocarta obtida em 1974, mostrando a existência de uma linha de costa bordejada por uma praia arenosa, contínua até a margem esquerda do estuário.

Fonte:COUTINHO, 1997

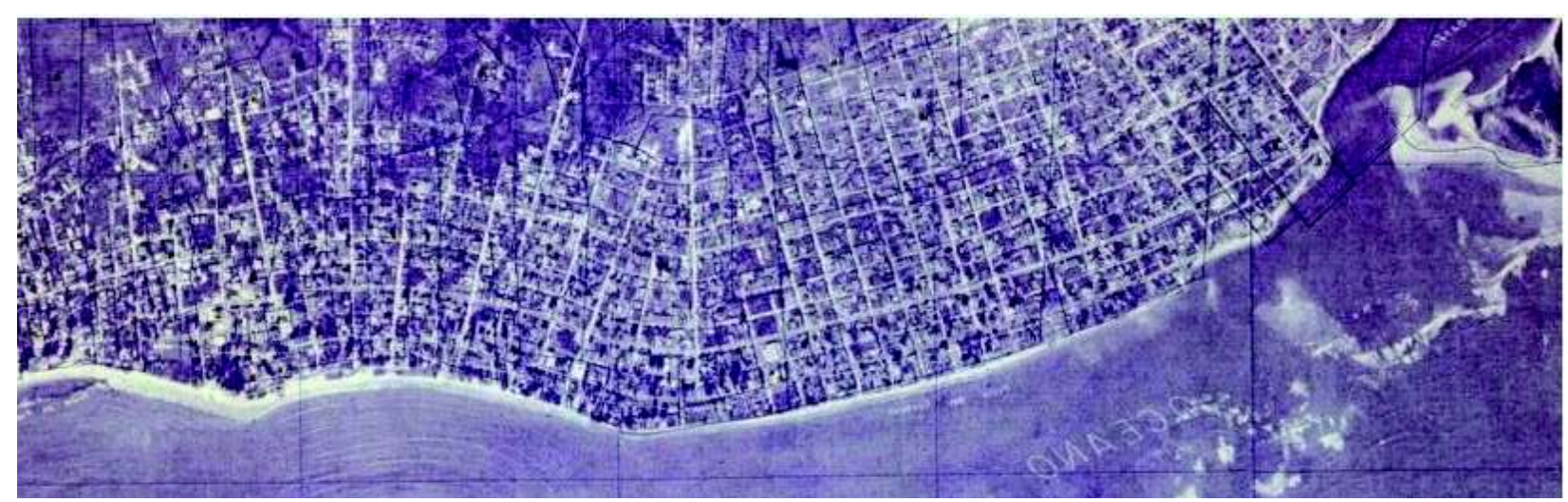

Figura 3 - Ortofotocarta obtida em 1986, mostrando a redução da faixa arenosa ao longo das praias e a acentuada erosão na margem esquerda do estuário.

Fonte:COUTINHO,1997.

A predominância da corrente de deriva litorânea se faz no sentido SE/NE, face os ventos alísios de SE atuam na área de estudo durante nove meses, podendo assim indicar a corrente litorânea como neta, sendo esta corrente responsável pela reposição das praias.

A área de estudo encontra-se descaracterizada no que concerne à totalidade dos subambientes praias. Neles observam-se as dunas maculadas pelo processo de urbanização, o estirâncio, com a presença de muitos muros de contenção, as praias artificializadas pela colocação de sedimentos não tecnicamente recomendados; a pós-praia sofrendo intensa ação antropogênica, tanto pela ação imobiliária, como pela engenharia costeira. Desses subambientes apenas a antepraia encontra-se conservada.

A área de estudo, por situar-se no mundo tropical, conduz à predominância do intemperismo químico sobre o físico. Os diversos tipos de intemperismo em consórcio, contribuem de forma 
decisiva para o aporte de sedimentos, em sua maioria provenientes de depósitos fluviais, que apresentam predominância de areia de quartzo, juntando-se ás outras fontes de sedimentos, com uma proporcionalidade de carga deposicional na ordem de $95 \%$ de sedimentos arenosos.

Durante Análise dos Perfis de Praia todo o período do estudo,o monitoramento da área foi efetuado entre os meses de julho/2005 e abril/2006, a pós-praia apresentou-se constituída por uma areia média $(0,3 \mathrm{~mm}$ a $0,4 \mathrm{~mm})$, enquanto o estirâncio apresentou uma composição granulométrica variando entre areia média e fina, dependendo da energia das ondas.

A maior variação textural foi encontrada no setor de antepraia, desde areia muito fina até grossa, sendo esta última constituída por fragmentos orgânicos. De modo geral, a declividade da praia é inferior a $10^{\circ}$ (COUTINHO,1997), compatível com o tipo de sedimento encontrado nas praias. A implantação dos perfis praiais foi função de análise para identificação do estado geral da praia, características gerais da praia, presença de recifes de arenito e/ou de corais, áreas de erosão ou sedimentação, entre outras

Ao longo da área estudada foram escolhidos quatro locais de perfis já estudados previamente por Coutinho (1997), com proposição de análise das autoras.

O primeiro deles (P-1),situado na entrada de Barra de Jangadas e, o último (P-4), situado na Curva do SESC, limite entra as praias de Candeias e Piedade.

Ao longo de toda Praia de Candeias, predomina a erosão, materializada pelo acentuado recuo da linha de costa, fato já demonstrado anteriormente através de imagens de satélite. A principal causa de erosão nas áreas de localização dos perfis corresponde a uma seqüência de proteções duras, produto da engenharia costeira, intensificada por uma fase inicial do sistema de enrocamento. Quando ocorre uma zona intersticial entre esse enrocamento e os recifes artificiais, acelera o processo de energia das ondas na área de descontinuidade dessas estruturas. Em função do alto grau de erosão em alguns trechos, a prefeitura do município de Jaboatão dos Guararapes realizou um engordamento da praia com sedimentos provenientes do Rio Jaboatão, entretanto, está técnica não vem surtindo efeito, pois se verifica uma perda quantitativa acelerada de sedimentos, indicando o não funcionamento técnico e operacional.

O perfil P-1, localizado entre a Latitude $8^{\circ} 13,14^{\prime}$ S e Longitude $34^{\circ} 55,29^{\prime} \mathrm{W}$, na entrada de Barra de Jangada, é caracterizado pela grande extensão do estirâncio (comparando-se aos demais perfis), resultado da presença de bancos arenosos em sua porção inferior, que se prolongam pela antepraia. O setor de pós-praia tem uma extensão em torno de $14 \mathrm{~m}$ ). Embora, de uma maneira geral, os levantamentos em P-1 mostrem uma aparência relativamente equilibrada, verificou-se, na verdade, uma taxa de erosão média anual de $22,48 \mathrm{~m} 3 / \mathrm{m} /$ ano. As taxas máximas ao longo do monitoramento foram de $4,75 \mathrm{~m} 3 / \mathrm{m} /$ dia para erosão, e de $3,05 \mathrm{~m} 3 / \mathrm{m} /$ dia para deposição.O monitoramento do perfil P-2, localizado entre a Latitude $8^{\circ} 12,70 \mathrm{~S}$ e Longitude $34^{\circ} 55,12 \mathrm{~W}$, norteou uma clara alternância de ciclos erosivos e deposicionais. Esta erosão foi também observada nos demais setores da praia.

O referido perfil não difere das características do perfil anterior,onde se observa a presença das estruturas duras representadas por espigões e muros de contenção, como também a falta de ordenamento no processo de urbanização, e a conseqüência da falta de saneamento básico do município, evidenciada pelas descargas de esgoto sanitário diretas para o oceano (Figura 4).

O perfil P-3 está localizado entre a Latitude $8^{\circ} 12,70 \mathrm{~S}$ e Longitude $34^{\circ} 55,12 \mathrm{~W}$. Trata-se de uma área reconhecida por um processo erosivo já observado em períodos anteriores, inclusive identificados nas ortofotocartas representadas pelas figuras 2 e 3 . 


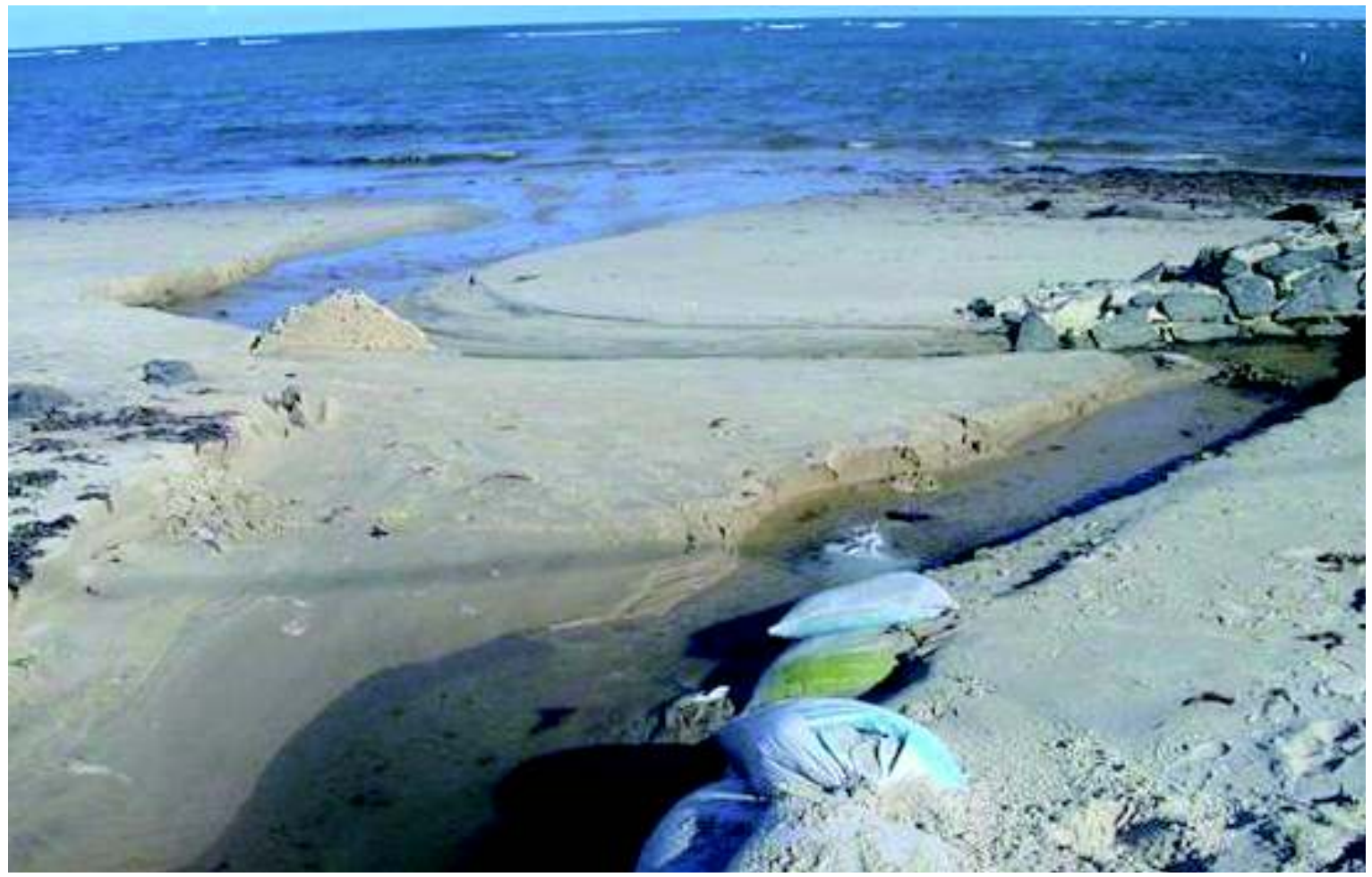

Figura 4 - Detalhe da emissão direta de esgoto doméstico. Ao fundo, observa-se presença de enrocamentos, Perfil 2. Fonte: A autora. 2005.

A taxa média de erosão anual é de 48,91 m3/m/ano (com demonstração de superioridade com relação às encontradas em P-1 e P-2). Tal taxa de erosão pode ser justificada através da forma de proteção executada. A construção de espigões nos outros perfis não apresenta a mesma identidade, nesta área a disposição da proteção é paralela (enrocamento), o que minimiza a ação da energia das ondas, interceptando, todavia, a penetração de sedimentos para retroalimentação da praia, através da corrente de deriva litorânea.

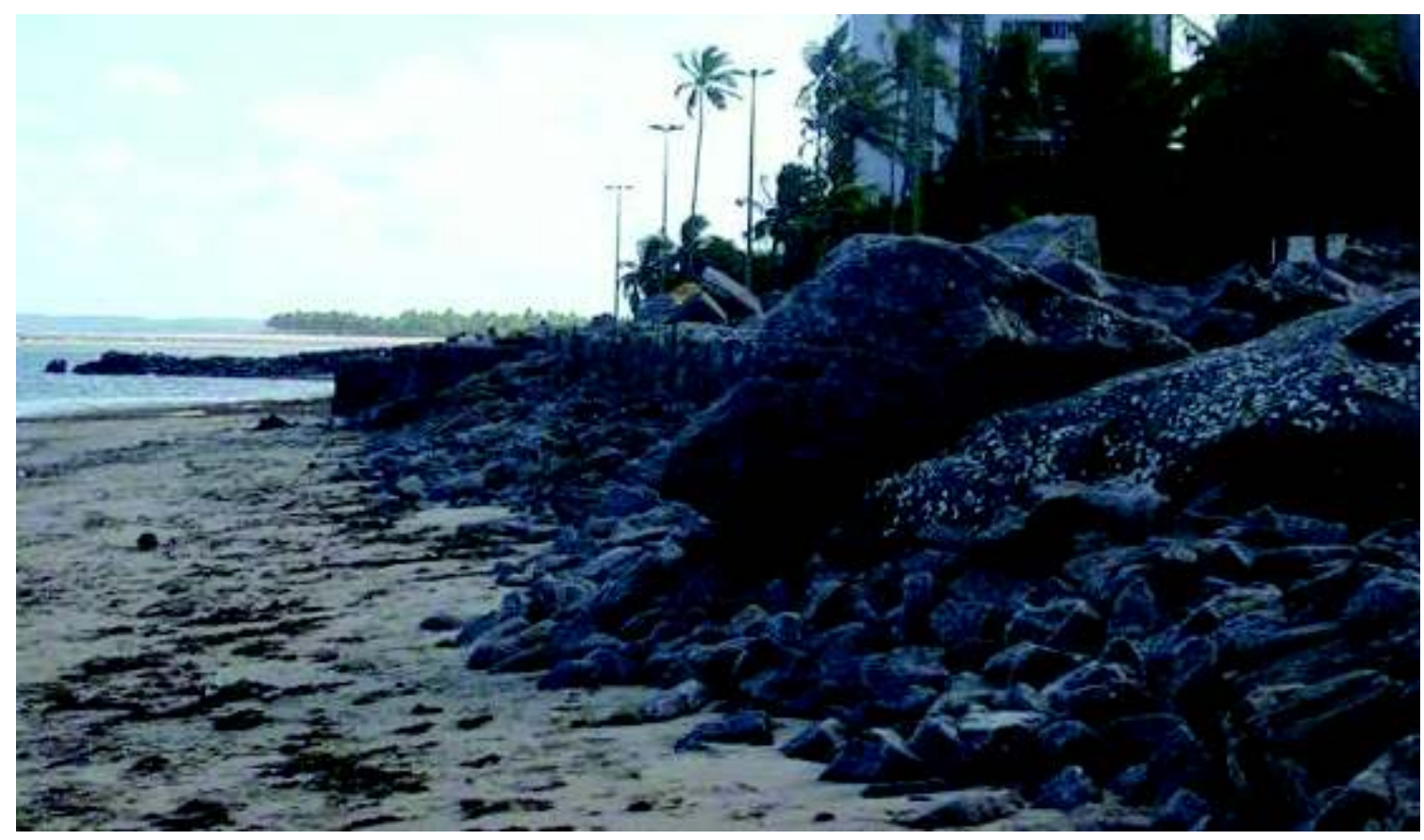

Figura 5 - Aspecto geral do trecho da Praia no Perfil 03. Fonte: A autora. 2005.

Mercator - volume 8, número 17, 2009: set./dez. 
O perfil P-4, localizado entre a Latitude $8^{\circ} 11,59^{\prime} \mathrm{S}$ e Longitude $34^{\circ} 54,86^{\prime} \mathrm{W}$, junto ao clube SESC de Piedade, apresentou, durante o período de estudo, uma leve tendência à acumulação de sedimento a barlarmar por efeito de um espigão (Figura 6), enquanto que a sotamar, a erosão foi intensa. Ocorreu um processo de engordamento artificial, entretanto, o problema não teve solução face à técnica utilizada. A reposição foi realizada com sedimentos do rio, quando deveria ser com os sedimentos dos bancos de areia da plataforma (Figura 6).

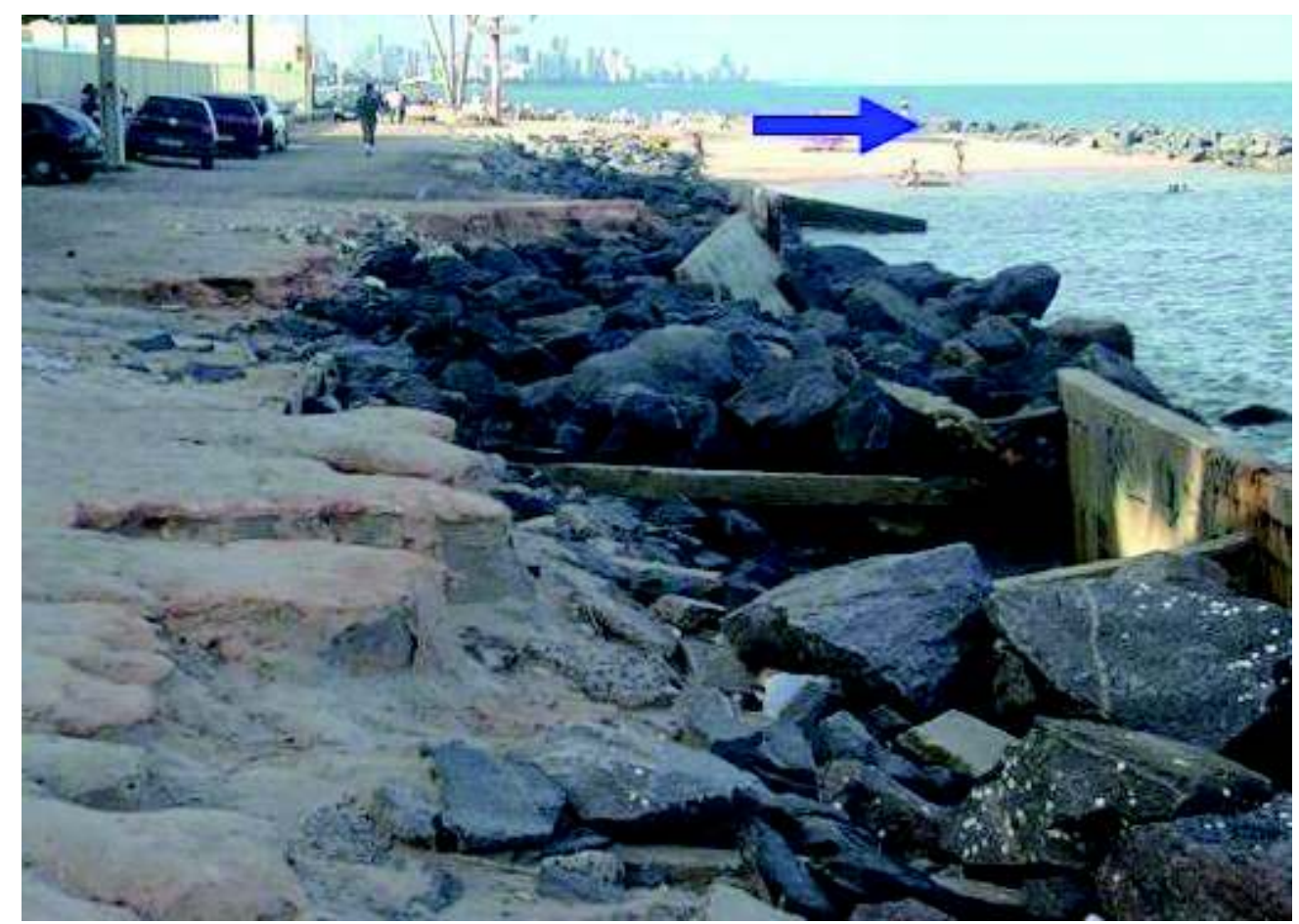

Figura 6 - Perfil 04, demonstrando uma acumulação de sedimentos em função da construção de um espigão indicado com a seta.

Fonte: A autora. 2005.

Resumindo as taxas médias de erosão/deposição, nota-se que, na Praia de Candeias, predomina uma erosão crescente, um fator preocupante, que deve ser definido como prioridade das várias ações que devem ser implementadas pelo poder público para a minimização dos processos de degradação atuantes na zona em pauta.

Não existe um método padronizado para o estudo morfo sedimentológico de praia (principalmente no que se refere a trabalhos de campo), nem tão pouco existe um modelo pré-concebido e indicado à determinação dos riscos de erosão na zona costeira, as formas de abordagem para os processos erosivos costeiros: erosão natural, que se desenvolve em condições de equilíbrio com o restante do meio físico, e a erosão antrópica, cuja intensidade, sendo superior às respostas compensatórias do meio físico, não permite a sua recuperação natural (DUARTE, 2002).

A dinâmica da praia de Candeias e seu entorno se caracteriza por estar afetada por processos constantes de transformação, tanto de origem humana como natural.

Entendem-se como causas naturais às marés, a ausência do aporte de areia, o surgimento de corpos arenosos, as correntes de retorno, a descontinuidade das linhas de recifes, a sazonalidade das praias e as barreiras hidráulicas produzidas pelos cursos fluviais.

No que se refere às marés, pode-se citar o processo descrito por Suguio et al (1985) onde o curso do ciclo mensal de maré, durante as marés de sizígia, corresponde a uma pequena transgressão, ocorre erosão na praia e sedimentação na antepraia, e durante as marés de quadratura, ocorre o processo contrário. É evidente que a linha de costa está em constante mutação como resultado da hidrodinâmica oceânica . 
A ausência do aporte de areia só não acontece no Perfil 1, em face da proximidade da foz do rio Jaboatão. Nos demais perfis (2, 3, e 4), os trechos que apresentam significativa quantidade de areia são resultado de reposição artificial de sedimentos. O Perfil 4 destaca-se por ser a área mais crítica de erosão, em função da intensificação da construção de obras artificiais. $\mathrm{O}$ aporte de sedimentos pelos rios permaneceu sempre pouco expressivo, pelo menos a partir do Holoceno, e o fraco material transportado ficou retido nos estuários formando os manguezais (COUTINHO,1997).

Quanto ao surgimento dos corpos arenosos, observou-se presença no Perfil 1, devido ao molhe hidráulico conjugado à presença de uma barra, que passa a interceptar a corrente de deriva litorânea, ocorrendo um desequilíbrio alterando a direção do fluxo dos sedimentos.

A corrente de retorno é outro elemento transformador das praias. Suguio (1992) sugere que tal corrente "é uma forte corrente que flui do litoral até o mar mais profundo", correspondendo ao movimento de retorno das águas acumuladas por sucessivos trens de ondas. Estas correntes (figura 16) apresentam três partes: a) corrente alimentadora; b) lugar para onde as correntes convergem; e c) parte onde a corrente se dissipa e depois se alarga. Tais correntes trazem consigo sedimentos que separam as áreas mais elevadas, indicando a ação erosiva. A continuidade da linha das barreiras de recifes proporciona a proteção das praias. Nas linhas descontínuas de recifes os espaços funcionam como facilitadores do aumento de energia das ondas, concentrando o processo de erosão na linha de costa (Figura 06), como se observa claramente no Perfil 4, onde a construção de obras artificiais com esta configuração caracteriza a área como mais crítica em termos de erosão (Figura 07). Três as causas de erosão que envolvem os processos antrópicos, se pode destacar a ocupação desordenada, a contaminação das praias, a diminuição da qualidade da água, as obras de construção duras (espigões, muros de contenção e enrocamentos), intensificando a erosão da linha de costa, a destruição dos mangues, a construção de barragens a montante do rio e a retirada de areia dos mesmos.

A erosão marinha, nas zonas costeiras, é um problema que está intimamente associado à falta de um planejamento urbano Outros fatores de ordem ambiental atuam fortemente para agravar este problema dentre os quais, aterros indiscriminados dos mangues e obras de engenharia que, quando executadas sem critérios globais, podem agravar ou provocar erosão nas áreas adjacentes.

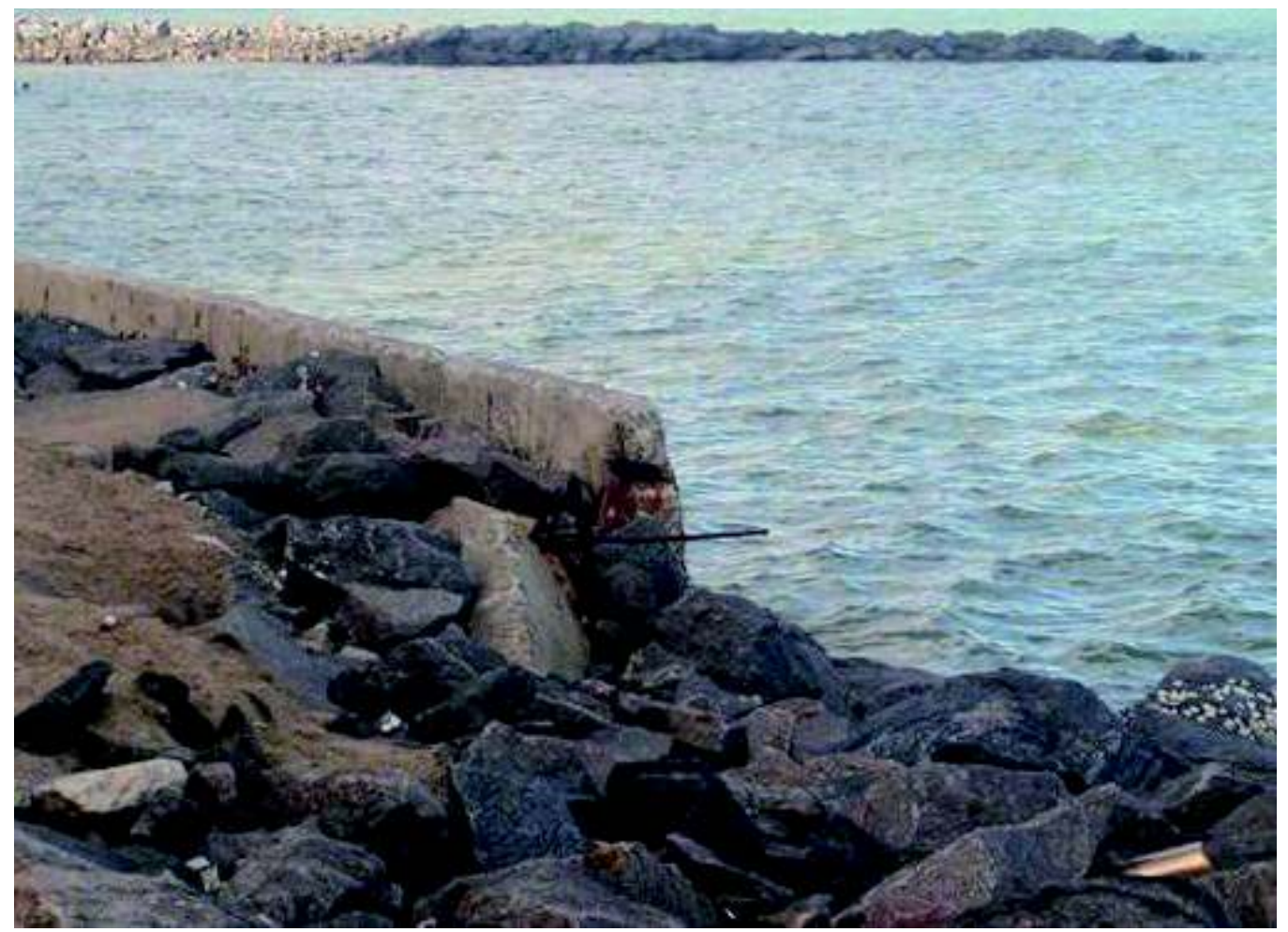

Figura 7 - Exemplo de construção artificial contribuindo diretamente para a erosão acelerada no perfil 04. Fonte: A autora. 2008.

Mercator - volume 8, número 17, 2009: set./dez. 
A exploração indiscriminada de areias das dunas, pós-praia e antepraia, para construção civil, agrava seriamente o déficit de sedimento nas praias, e acelera seu processo de emagrecimento. Grande concentração de construções: edifícios, passeios, estradas, diques, entre outros no domínio litoral, sobre as dunas frontais e a pós-praia, além de agredir a paisagem, contribuem para aumentar a erosão das praias, que ficam amputadas de setores responsáveis pelo seu equilíbrio. A concentração das mais variadas construções, desencadeia a contaminação da praia e a diminuição da qualidade da água, com efluentes de esgoto domésticos e industrial, despejados sem nenhum tratamento prévio. Um grave problema de poluição foi confirmado pelos índices de DBO, OD e Coliformes no local, monitorados pela CPRH no período de 2001 a 2004, aferidos na foz do Rio Jaboatão como se confirmam nas figuras 8,9 e 10 .

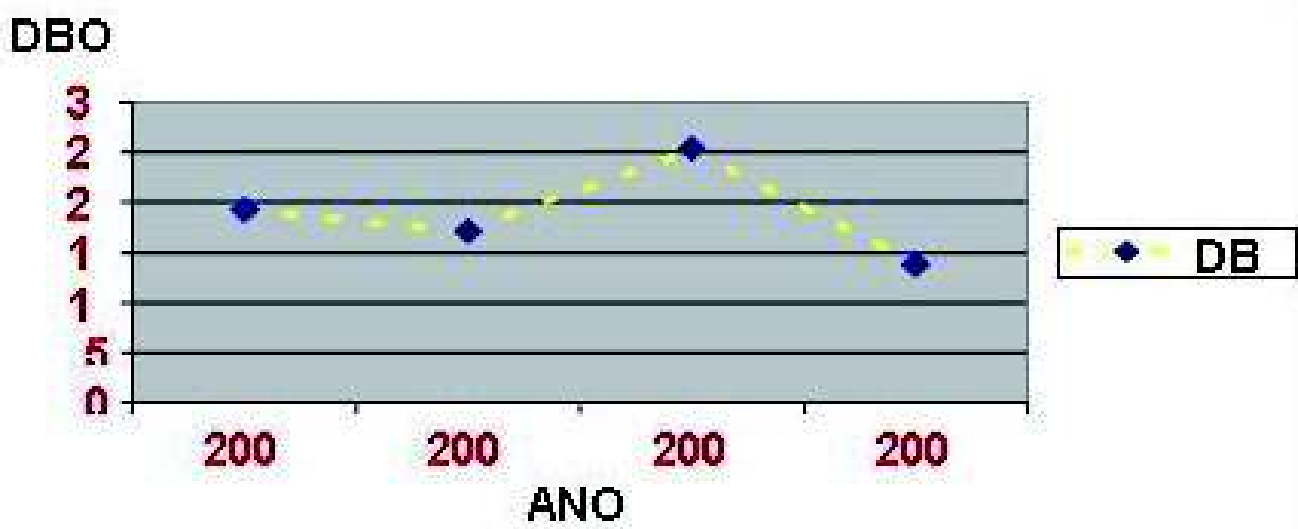

Figura 8 - Índice de DBO monitorado pela CPRH na foz do rio Jaboatão no período de 2001 a 2005.

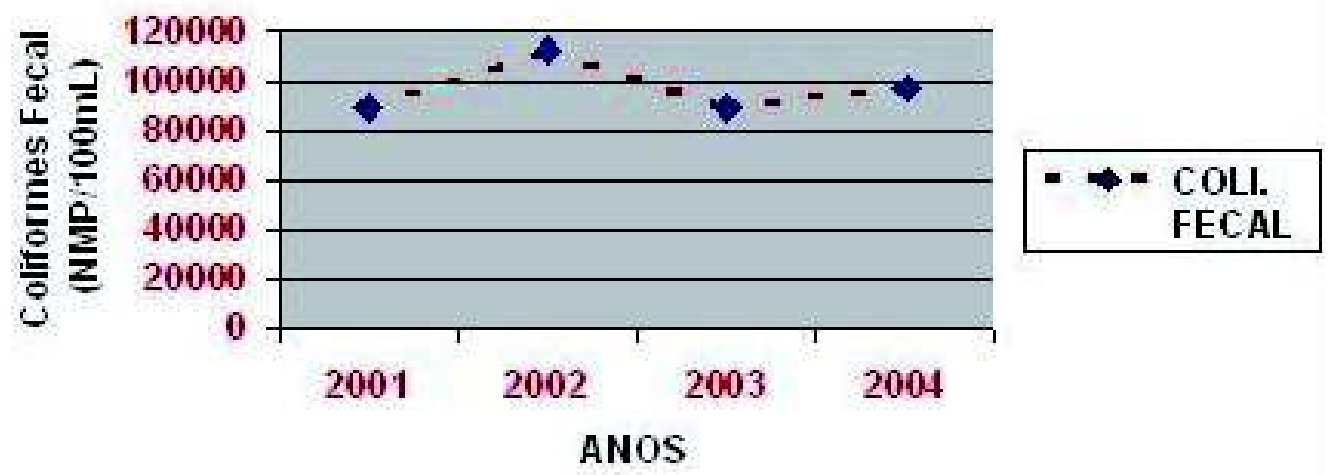

Figura 9 - Índice de Coliformes fecal monitorado pela CPRH na foz do rio Jaboatão no período de 2001 a 2005.

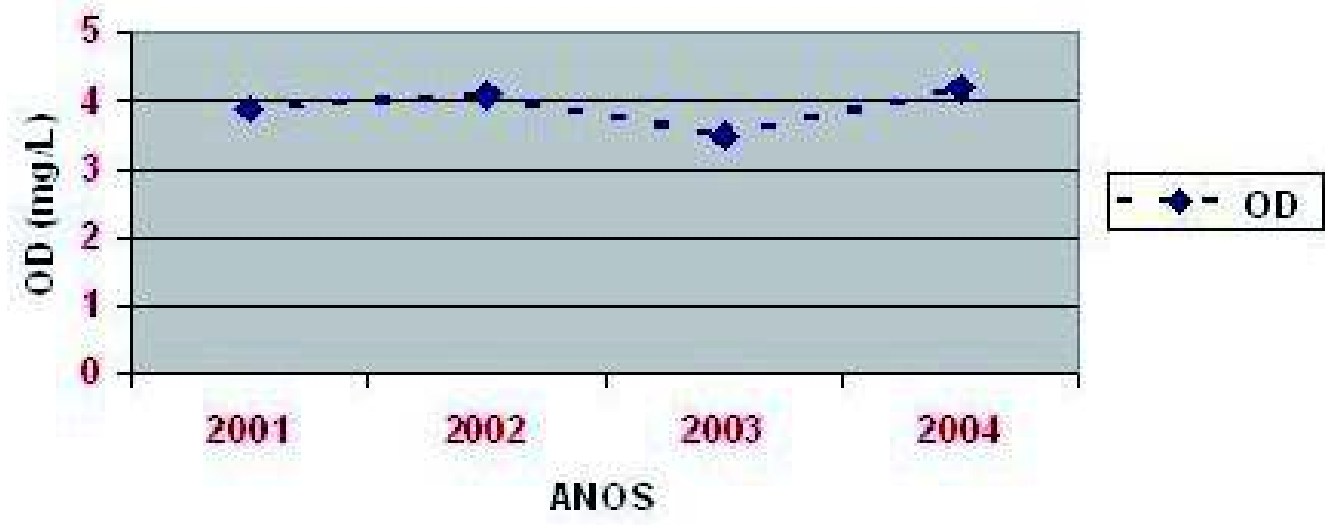

Figura 10 - Índice de OD monitorado pela CPRH na foz do rio Jaboatão no período de 2001 a 2004. Fonte: www.cprh.gov.br, 2005 
Os impactos ambientais identificados no campo, demonstram o intenso grau de descaracterização da paisagem. Convém destacar que tais impactos possuem causas naturais e antrópicas. No entanto, as causas antrópicas representam o maior poder de alteração/degradação, visto que delega aos fatores naturais apenas uma atuação coadjuvante. Desse modo, fica clara a necessidade do homem reavaliar suas ações no sentido de exercer menos pressão num ecossistema frágil como o litorâneo e historicamente degradado.

\section{IDENTIFICAÇÃO E AVALIAÇÃO DOS IMPACTOS}

As ações antrópicas que trazem desequilíbrio ao ambiente, particularmente ao espaço costeiro, têm suas bases voltadas para a cultura urbana, onde os problemas econômicos se misturam com as verdadeiras necessidades vitais. Como conseqüência, constata-se que o meio ambiente passa por transições e transformações profundas, repercutindo na própria vida humana.

Todas as considerações sobre as causas (ações), os efeitos (impactos), determinados fatores e elementos (físicos, bióticos, perceptuais e socioeconômicos), foram investigados, identificados e avaliados na área em questão e seu entorno, com exceção da flora e fauna da lagoa Olho d'água.

O valor da importância de cada impacto se calculou a partir da multiplicação dos valores da Magnitude e da Importância, por ser os indicadores principais, e da soma da Duração e Reversibilidade.

Foram identificadas 9 ações e 30 impactos (Tabela 1). O impacto de maior pontuação foi de número 13 (Tabela 02). Do total de 24 impactos negativos, 11 representam o valor máximo, aferido através da metodologia proposta na presente pesquisa, fator que justifica o intenso grau de descaracterização da paisagem.

É importante salientar os valores atribuídos a cada impacto (Tabela 2). A identificação dos impactos demonstrou que as ações tiveram grande repercussão. Os 30 impactos foram classificados em: 4 positivos, 2 previsíveis e 24 negativos (Tabela 2).

Tais valores representam considerável pontuação. Outro fator preocupante é o grau de variação entre os impactos negativos que representam uma pontuação entre -19 e -193 (Tabela 3), o que indica uma complexidade da influência, em diferentes intensidades, dos impactos na configuração geral da paisagem.

No que concerne à intensidade dos impactos, destaca-se a média de valoração dos impactos positivos, que são menores em relação aos negativos. O processo é resultante das sucessivas ações negativas pautadas no imediatismo e sem fundamentação científica, que atuam como agente catalisador das graves conseqüências identificadas com os impactos negativos na região em questão.

A matriz de evolução dos impactos (Tabela 3) demonstra uma significativa transformação da paisagem, sobretudo nos fatores e elementos físicos, quando juntos apresentam valor -504. Em segundo lugar, os fatores e elementos bióticos, com valor -340 , e, por último, os fatores perceptuais e sócio-econômico (o único fator com impactos positivos), com pontuação -29.

Em relação aos fatores e elementos físicos, vislumbra-se uma predominância de ações envolvidas no Relevo, solos (ambos com 8 ações), e Praias-Bermas (com 7 ações), que desencadearam o total de 37 impactos com valoração de -402 (Tabela 3).

Com interpretação dos resultados obtidos a partir da metodologia proposta por Leopold \& Gomez (1998), adaptada por Oliveira (1998), é possível conhecer a dinâmica geral da área estudada, e identificar os impactos deflagrados pelas várias ações nos fatores e elementos. Tal conhecimento é imprescindível para futuras propostos de recuperação da região que vise reverter, ou ao menos minimizar os impactos atuantes direta ou indiretamente na área em questão. 
Tabela 1- Identificação das Ações, Fatores e Impactos

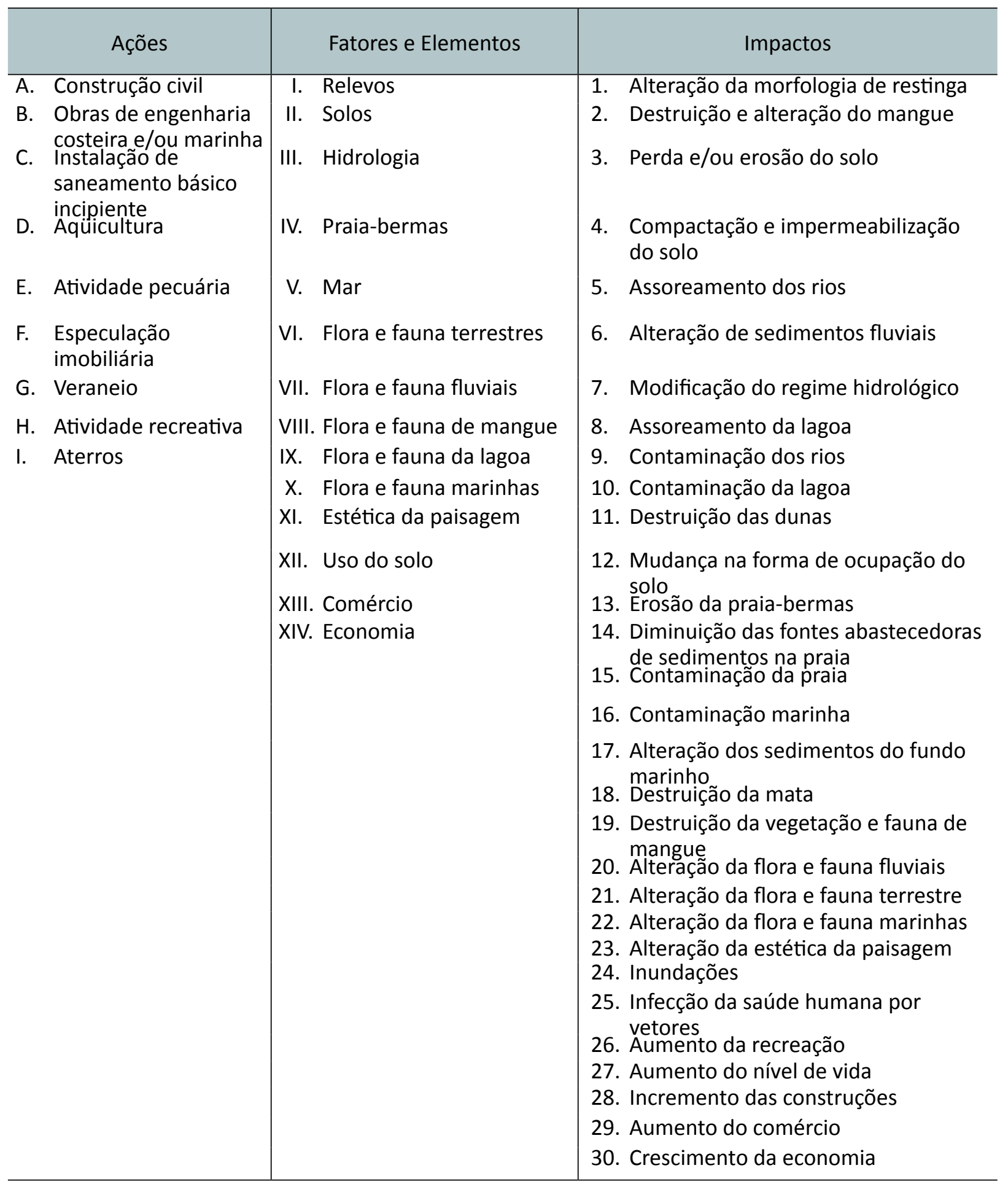


Tabela 2 - Valoração Qualitativa e Quantitativa dos Impactos

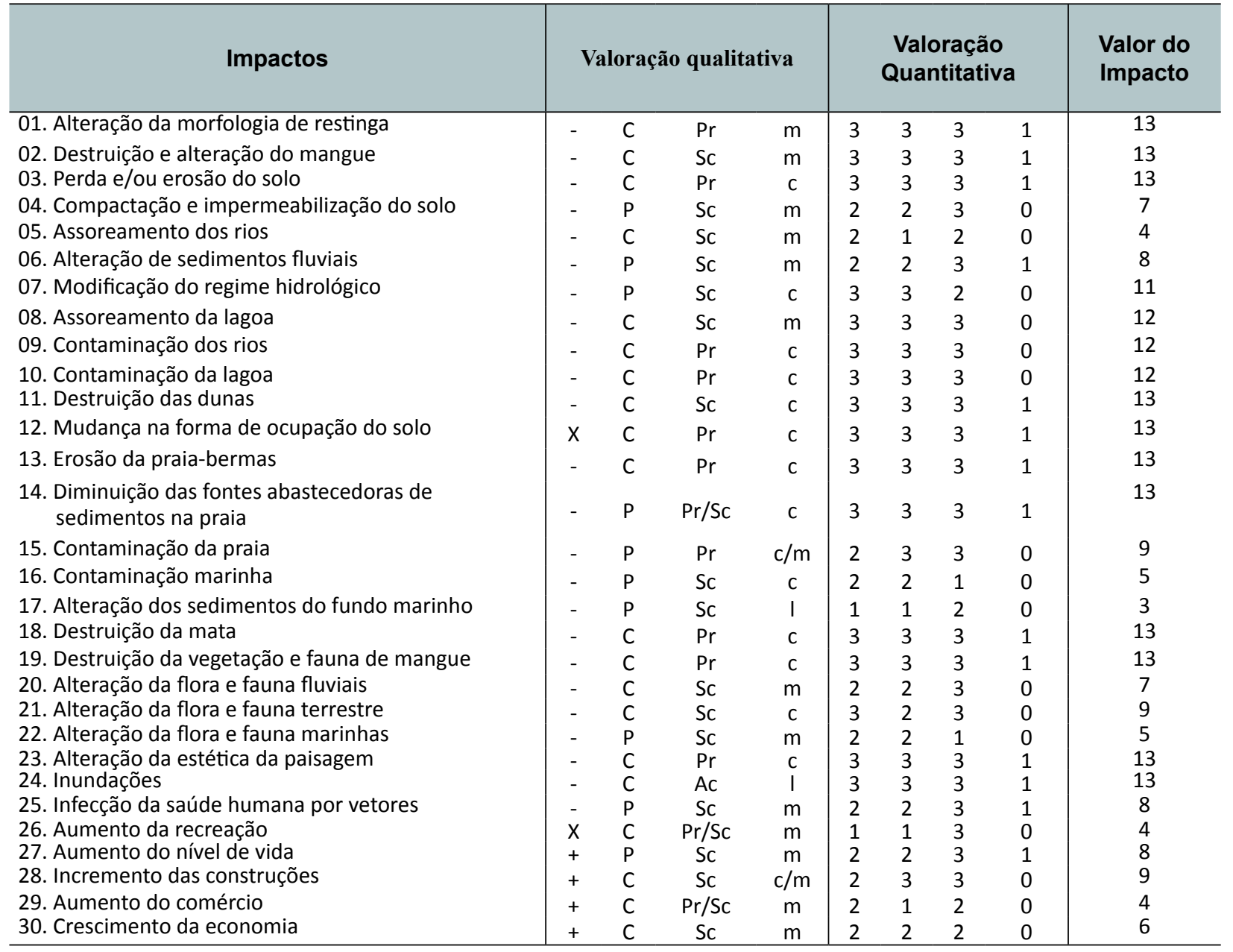

Os problemas relacionados com a agressão das fronteiras, raramente tiveram origem em causas simples, e, em geral, resultaram de uma série de características independentes e complexas.O sistema costeiro, em sua área agredida pelo mau uso do solo, passou por desafios sérios e difíceis, que comprometeram a qualidade ambiental devido a sua irreversibilidade. Esse fato traz à tona a questão dos interesses públicos e privados em conflitos agravados por incentivos econômicos mal planejados e aplicados. Isso porque nem sempre os anseios da população e meio ambiente fazem parte dos interesses políticos.

O sistema costeiro, como já foi dito anteriormente, passa por graves problemas ambientais, isso ocorre principalmente devido à ocupação urbana desordenada, à descontinuidade administrativa, à especulação imobiliária, ao aumento populacional e à pressão habitacional, entre outros fatores. A situação torna-se mais grave quando o trecho de ambiente a ser agredido é a linha de costa, um ecossistema que naturalmente já sofre pressão entre dois outros grandes domínios: o continental e o marinho. 
Tabela 3 - Matriz de Evolução dos Impactos

\begin{tabular}{|c|c|c|c|c|c|c|c|c|c|c|c|}
\hline \multicolumn{2}{|c|}{ Fatores e Elementos Ambientais } & A & B & C & D & $\mathrm{E}$ & Jes & G & $\mathrm{H}$ & 1 & Total \\
\hline \multirow{4}{*}{ Físicos } & Relevo & -26 & -37 & & -26 & -13 & -39 & -13 & -26 & -13 & -193 \\
\hline & Solo & -13 & -20 & -13 & -20 & -13 & & -13 & $\mathrm{X} 13$ & -20 & -112 \\
\hline & Hidrologia & -35 & $\mathrm{X} 13$ & -12 & -36 & & & & & $\mathrm{X} 13$ & $\begin{array}{l}\times 39 \\
-83\end{array}$ \\
\hline & Praia-Berma & -13 & -13 & -14 & & & -13 & -9 & -22 & -13 & -97 \\
\hline \multirow{5}{*}{ Bióticos } & Mar & & -3 & -5 & -3 & & -3 & -5 & & & -19 \\
\hline & $\begin{array}{l}\text { Flora e Fauna } \\
\text { Terrestres }\end{array}$ & -9 & -9 & -9 & & -9 & -9 & -9 & -9 & -9 & -72 \\
\hline & $\begin{array}{l}\text { Flora e Fauna } \\
\text { Fluviais }\end{array}$ & -7 & -7 & -7 & & -7 & -7 & -7 & & -7 & -49 \\
\hline & $\begin{array}{l}\text { Flora e Fauna de } \\
\text { Mangues }\end{array}$ & -13 & -13 & -13 & -13 & & -13 & & & -13 & -78 \\
\hline & $\begin{array}{l}\text { Flora e Fauna } \\
\text { Marinhas }\end{array}$ & & -5 & -5 & -5 & & -5 & -5 & & & -25 \\
\hline \multirow{5}{*}{ Perceptual } & $\begin{array}{l}\text { Estética da } \\
\text { Paisagem }\end{array}$ & -13 & -13 & -13 & -13 & -13 & -13 & -13 & -13 & -13 & -117 \\
\hline & Uso do solo & -13 & $\mathrm{x} 13$ & -8 & $\mathrm{X} 13$ & -8 & $\mathrm{X} 13$ & $\mathrm{X} 13$ & $\mathrm{X} 13$ & $\mathrm{X} 13$ & -29 \\
\hline & & +9 & & & & & & & & & +9 \\
\hline & Comércio & $\begin{array}{c}\mathrm{X} 13 \\
+4\end{array}$ & & $\mathrm{X} 13$ & +6 & $\begin{array}{c}X 13 \\
+4\end{array}$ & +4 & +4 & +4 & +8 & $\begin{array}{c}\times 117 \\
+34\end{array}$ \\
\hline & Economia & +15 & & & +6 & +6 & +6 & +6 & +6 & $\frac{X 4}{+6}$ & $\frac{x 4}{+51}$ \\
\hline \multirow{3}{*}{ Sócio-econômico } & Total & -142 & -120 & -99 & -116 & -63 & -102 & -74 & -70 & -88 & -874 \\
\hline & & +28 & & & +12 & +10 & +10 & +10 & +10 & +14 & +94 \\
\hline & & $\mathrm{X} 13$ & $\mathrm{X} 26$ & $\mathrm{X} 13$ & $\mathrm{x} 13$ & $\mathrm{X} 13$ & $\mathrm{X} 13$ & $\mathrm{X} 13$ & $x 26$ & $\mathrm{X} 30$ & $\mathrm{X} 160$ \\
\hline
\end{tabular}

\section{CONSIDERAÇÕES FINAIS}

O desconhecimento da tendência da evolução da linha de costa tem conduzido à ocupação indevida dirigida à urbanização. Este fato vem sendo o principal causador das grandes transformações relacionadas à alteração da morfologia, destruição da vegetação e contaminação das praias. Estudos recentes têm revelado que a elevação do nível do mar e o conseqüente recuo da linha de costa são fenômenos inquestionáveis, e devem ser levados em conta na elaboração de qualquer política de gestão costeira. Esses estudos recomendam, ainda, que seja delimitado todo o espaço costeiro, desde a pós-praia até a antepraia, e que seja proibida também a retirada de areia.

Para se entender o processo de deterioração do litoral de Jaboatão dos Guararapes é preciso considerar que, inicialmente, as praias e dunas estavam em equilíbrio natural com a costa, proporcionando um ambiente de alto valor paisagístico. Qualquer movimento (positivo ou negativo) da linha de costa era compensado pelas trocas de areia entre a alta praia e as barras erenosas da antepraia.

Com a urbanização maciça avançando sobre a pós-praia em direção ao mar, houve invasão e degradação do espaço costeiro. As primeiras construções guardavam ainda certa distância da linha d'água, o que permitia à costa conservar suas estruturas naturais de defesa, principalmente a praia. 
Com o aumento da pressão imobiliária, destruíram-se muitos cordões arenosos e a urbanização se estendeu sobre a pós-praia de forma desordenada, chegando cada vez mais próximo à linha d'água.

As praias foram as que mais sofreram com esse modelo danoso de ocupação do solo. Em alguns trechos de Candeias, a praia praticamente desapareceu. Muitas vezes o desaparecimento da praia chega a tal extremo que o mar ataca diretamente as próprias edificações, que se protegem construindo estruturas de defesa.

\section{REFERÊNCIA BIBLIOGRÁFICA}

AGÊNCIA ESTADUAL DE MEIO AMBIENTE E RECURSOS HÍDRICOS. Bacias Hidrográficas. Relatório de Monitoramento de Bacias Hidrográficas do Estado de Pernambuco - 2000 - 2004. Disponível em: < http://www.cprh.pe.gov.br/ >. Acesso em: 31 out. 2005.

BORBA, A. L. S. Estudos sedimentológicos, morfodinâmicos e da vulnerabilidade das praias da Piedade, Candeias e Barra de Jangadas - município de Jaboatão dos Guararapes. 1999.

CARVALHO, R.F; Coutinho, P. N. Evolução da área da Lagoa Olho d'àgua. In: Simpósio de Geologia do Nordeste, Natal. Atas. Natal: SBG, p. 180-201, 1979.

CHAVES, N.S. Beachrocks do Litoral Pernambucano: Estudo Sedimentológico e Análise Isotópica. 1996. Dissertação (Mestrado). Centro de Tecnologia e Geociências. Universidade Federal de Pernambuco. Recife. COUTINHO, P.N. Estudo da Erosão marinha nas Praias de Piedade e de Candeias e no Estuário de Barra de Jangada. Município de Jaboatão dos Guararapes-PE. Relatório Final, Recife, 1997.

DUARTE, R.X. Caracterização Morfo-sedimentológica e Evolução de Curto e Médio-Prazo das Praias do Pina, boa Viagem e Piedade, Recife/Jaboatão dos Guararapes - PE. 2002. Dissertação (Mestrado). Universidade Federal de Pernambuco. Recife.

FILHO, M.F.. Origem da Planície do Recife. Estudos Geológicos - Revisão geológica da faixa sedimentar costeira de Pernambuco, Paraíba e parte do Rio Grande do Norte. Universidade Federal de PE, v. 10, 252 p. 157-176 (Série B - Estudos e Pesquisas) Recife, 1991.

LEOPOLD, A.; GOMES, O. Matriz de evaluación de impactos. Curso Máster E.I.A. Instituto de Investigaciones Ecológicas. Málaga, Módulo 7, p. 57-58, 1994.

OLIVEIRA, N. Problemas Geomorfólogo - ambientales de lãs Restingas y Mangles em Pernambuco y Cuba. 1998. Instituto de Geografia Tropical, La Habana. Tese (Doutorado).

SUGUIO, K. Flutuação do nível relativo do mar durante o quaternário superior ao longo do litoral brasileiro e suas implicações na sedimentação costeira. Rev. Brasileira de Geociências: São Paulo v.15, n. 4, p. 273-286, 1985.

Trabalho enviado em setembro de 2009

Trabalho aceito em dezembro de 2009

Mercator - volume 8, número 17, 2009: set./dez. 